\title{
Reflexiones en torno a la contagiosidad de la nueva cepa de SARS-CoV-2 y su prevención con vacunas mARN
}

\section{Reflections on SARS-CoV-2 new strain contagiousness and its prevention with mRNA vaccines}

José L. García-Vigil1* y José L. García-Álvarez²

${ }^{1}$ Universidad Nacional Autónoma de México, Facultad de Medicina, Departamento de Farmacología; ${ }^{2}$ Instituto Mexicano del Seguro Social, Centro Médico Nacional Siglo XXI, Hospital de Especialidades. Ciudad de México, México

En Inglaterra se ha identificado una nueva cepa de COVID-19, probablemente por mutación genética, lo que puede explicar el rebrote de la pandemia y la gran mortalidad en Europa o, al menos, en dicho país. Aparentemente apareció desde septiembre de 2020, pero la mayor manifestación clínica y epidemiológica se observó después. La nueva cepa ha sido denominada VUI-202012/01, ya que fue la primera variante investigada en diciembre de 2020. Public Health England notificó que al 13 de diciembre se habían identificado 1108 casos con la nueva variante en el sur y este de Inglaterra. Se indicó que el virus sería más difícil de controlar si se propagaba más rápido, dado que más personas se enfermarían en un periodo más corto. ${ }^{1,2}$

La Organización Mundial de la Salud aconseja a todos los países que aumenten la secuenciación de los virus SARS-CoV-2, siempre que sea posible, compartan datos a nivel internacional e informen si se encuentran las mismas mutaciones preocupantes. Es clave detener la propagación en su origen, por lo que es necesario continuar con todas las medidas sociales y de salud pública básicas que funcionan. Cuantas más personas se vacunen, más se reducirá la circulación del virus y disminuirá su potencial de nuevas mutaciones y variantes. ${ }^{3}$

La vacuna funciona porque el cuerpo se expone a una sección del código genético del virus (antígeno del pico o espícula), para que el sistema inmunológico despliegue sus mecanismos de defensa. Es poco probable que un solo cambio en COVID-19 disminuya la efectividad de este proceso; sin embargo, podría suceder que con el tiempo se produzcan más mutaciones, como ocurre cada año con la gripe secundaria al virus de la influenza. ${ }^{4}$

\section{Bibliografía}

1. Barret A. COVID-19: ¿Cuál es la nueva variante del coronavirus? Reino Unido: Science Focus [Internet]; 2020.

2. Gallagher J. 'New variant' of coronavirus identified in England. Reino Unido: News BBC, Sec. Health [Internet]; 2020 Dec 14. Disponible en: https://www.bbc.com/news/health-55308211

3. World Health Organization [Internet]. Suiza: WHO supports European countries' response to new virus variant; 2020. Disponible en: https:// www.euro.who.int/en/health-topics/health-emergencies/pages/news/ news/2020/12/who-supports-european-countries-response-to-new-virus-variant

4. Ahmed I. Messenger RNA: How a long shot idea led to COVID-19 vaccines. Medical Xpress [Internet]; 2020; Dec 16. Disponible en: https:// medicalxpress.com/news/2020-12-messenger-rna-shot-idea-covid-.html

\section{Correspondencia:}

*José L. García-Vigil

E-mail: pataloca5005@gmail.com
Gac Med Mex. 2021;157:332

Disponible en PubMed

Fecha de aceptación: 14-01-2021

DOI: 10.24875/GMM.20000972

0016-3813/C 2019 Academia Nacional de Medicina de México, A.C. Publicado por Permanyer. Este es un artículo open access bajo la licencia CC BY-NC-ND (http://creativecommons.org/licenses/by-nc-nd/4.0/). 